\title{
EXTRACTS OF MINT AND TEA AS GREEN CORROSION INHIBITORS FOR MILD STEEL IN HYDROCHLORIC ACID SOLUTION
}

\author{
M. A. BEDAIR ${ }^{(A, *)}$, M.S. METWALLY (A), S.A. SOLIMAN ${ }^{(A)}$, A.M. AL-SABAGH ${ }^{(B)}$, A.M. SALEM ${ }^{(A)}$, \\ AND T.A. MOHAMED ${ }^{(\mathrm{C})}$. \\ Departments of (a) Chemistry, Faculty of Science (Men's Campus), Al-Azhar University, Nasr City 11884, Cairo, \\ (b) Egyptian Petroleum Research Institute (EPRI). Nasr Citv. (c) Central Laboratories of Health. Cairo. Egvpt.
}

\begin{abstract}
The corrosion inhibition of mild steel in 1.0 M hydrochloric acid by the extracts of Stems of Mint (SM), Leaves Mint (LM), Caffeine (CE), and Tea extract (TEX) has been studied as cheap and eco-friendly inhibitors using weight loss, electrochemical impedance spectroscopy, and potentiodynamic polarization techniques. Efficiency was found to increase with increasing concentrations of the extracts. The effect of temperature on the corrosion behavior of mild steel in $1.0 \mathrm{M} \mathrm{HCl}$ on addition of extracts was also studied. The inhibition is assumed to occur via adsorption of the inhibitor molecules on the metal surface. The adsorption of the molecules of the extract on the mild steel surface obeyed the Langmuir adsorption isotherm. The results obtained showed that the extracts of Mint (stems, leaves) and Tea (Caffeine, TEX) are mixed type inhibitors and could serve as an effective inhibitor of the corrosion of mild steel in $1.0 \mathrm{M}$ hydrochloric acid media.
\end{abstract}

Key words: Corrosion inhibition; eco-friendly inhibitors, potentiodynamic polarization, weight loss.

\section{INTRODUCTION}

Corrosion is a common phenomenon in industries, and it attracts considerable amount of interest because of its hazardous nature on metals[1]. The results of corrosion in effects detrimental to the usage of the material are considered. Exclusively physical or mechanical processes such as melting or evaporation, abrasion or mechanical fracture are not included in the term corrosion[2]. In many industries, acid solutions are used frequently for acid pickling, industrial cleaning, acid descaling, oil-well acid in oil recovery, and the petrochemical processes [3-5], which leads to corrosive attack of metals. Generally, the inhibitors are used in these processes to control the metal dissolution as well as the acid consumption. Most of the inhibitors are organic substances[6-8]; however, inorganic substances[9] and polymeric materials[10 -12] were also used. Although high anticorrosion potential was exhibited by many organic molecules[13], they pollute the environment during their synthesis and applications[14]. Natural products were being studied for their corrosion inhibition potential as they are more environmentally friendly, showing good inhibition efficiency with low risk of environmental pollution[15,16]. The uses of natural products from plant extracts which are rich in tannins[17-19], black pepper extract[21], Lawsonia[22], and Opuntia extract[23]; also extracts of various parts of the plant have been used as corrosion inhibitors from leaves [24-26] and roots [27, 28], are environmentally friendly, nontoxic and relatively less expensive. Also, they are easily biodegradable. However, this bio-degradability limits the storage and longterm usage of plant extracts [29]. The inhibition efficiency of plant extracts have been evaluated at low and high temperatures [30-35].

Thus, this manuscript aims at investigation of the corrosion inhibition effect of some selected natural products as stems, leaves of mint and black tea extracts on mild steel in $1.0 \mathrm{M} \mathrm{HCl}$. The assessment of the corrosion behavior has been studied using weight loss, electrochemical impedance spectroscopy (EIS), and potentiodynamic polarization measurements. Kinetic and activation parameters that control metal corrosion have been evaluated.

\section{Experimental}

\subsection{Inhibitor Extraction}

\section{A. Mint extracts:}

The leaves and stems of the plants Mint (SM, LM) were taken and cut into small pieces, and they were dried in an air oven at $80^{\circ} \mathrm{C}$ for 2 hours. $20 \mathrm{~g}$ of the sample were refluxed in $100 \mathrm{ml}$ distilled water for $2 \mathrm{~h}$. The refluxed solution was then filtered carefully, double distilled water as the stock solution, and the concentration of the 
stock solution was expressed in terms of $\%(\mathrm{v} / \mathrm{v})$. $[36,37]$.

\section{B. Tea extracts:}

Black tea sample (Camellia sinensis) was purchased from a local market. For tea water extraction (TEX), the principle of the method is the extraction of soluble matter from a test portion $(3 \mathrm{~g})$ by boiling water $(300 \mathrm{ml})$ under reflux, filtration, washing, drying and weighing of the hot-water-insoluble residue then calculation of the water extract [38]. For Caffeine extraction (CE), $5 \mathrm{~g}$ of the black tea sample were boiled in $400 \mathrm{ml}$ for $30 \mathrm{~min}$. The dichloromethane is used as a solvent to extract caffeine from aqueous extract of tea powder because caffeine is more soluble in dichloromethane. The dichloromethane - caffeine mixture can then be separated on the basis of the densities of both dichloromethane and water because dichloromethane $[\mathrm{p}=(1.325 \mathrm{~g} /$ $\mathrm{ml}$ at $25^{\circ} \mathrm{c}$ )] is more denser than water. Remaining water is separated from dichloromethane by drain out the dichloromethane through separating funnel, thus dichloromethane passed through the funnel while polar solvents such as water is still remains in the funnel. Water and dichloromethane is slightly soluble in each other. So, after separating the solvents, remaining water will remain above the organic layer. Mainly anhydrous sodium sulfite was used for the removal of water from organic layer. The product after evaporation of the dichloromethane solvent is a residue of yellowish green - white crystalline caffeine[39].

\subsection{Specimen Preparation}

Tests were performed on steel of the following composition: $(0.29 \% \mathrm{C}, 1.25 \% \mathrm{Mn}, 0.03 \%$ $\mathrm{P}, 0.03 \% \mathrm{~S}, 0.27 \% \mathrm{Si}$, and the remained is $\mathrm{Fe}$ ). The mild steel (MS) samples were taken and were polished using different grades of abrasive papers from 400 up to 1200 before the analysis. The MS specimens of size $(2 \mathrm{~cm} \times 2 \mathrm{~cm} \times$ $0.1 \mathrm{~cm}$ ) were used for the weight-loss studies, whereas specimens with an exposed area of 8.8 $\mathrm{cm}^{2}$ were used for other studies.

\subsection{Solutions}

The aggressive solutions, $1.0 \mathrm{M} \mathrm{HCl}$, were prepared by dilution of analytical grade $37 \%$
$\mathrm{HCl}$ with distilled water. The concentrations of the prepared plants extracts used were: $100 \mathrm{ppm}$, $300 \mathrm{ppm}, 500 \mathrm{ppm}$ and $700 \mathrm{ppm}$.

\subsection{Electrochemical Measurements}

Electrochemical experiments were carried out using a Voltalab 40 Potentiostat PGZ 301 in a conventional electrolytic cell with three-electrode arrangement: saturated calomel reference electrode (SCE), a platinum rod as a counter electrode and the working electrode (WE) had the form of rod from mild steel. Prior to each experiment, the specimen was treated as in weight loss measurements. The electrode potential was allowed to stabilize $30 \mathrm{~min}$ before starting the measurements. The electrode area exposed to the corrosive solution is $1 \mathrm{~cm}^{2}$. All experiments were conducted at $25{ }^{\circ} \mathrm{C}$. Potentiodynamic polarization curves were obtained by changing the electrode potential automatically (from -1000 to $-300 \mathrm{mV}$ vs. SCE) at open circuit potential with a scan rate of $2 \mathrm{mV} \mathrm{s}^{-1}$.

\subsection{Weight loss measurements}

The experiments were carried out using mild steel specimens. They were abraded with different grade of emery paper washed with distilled water and dried in acetone and warm air. The precleaned and weighed coupons were suspended in beakers containing the test solutions using glass hooks and rods. Tests were conducted under total immersion conditions in $100 \mathrm{ml}$ of the aerated test solutions. To determine weight loss with respect to time, test coupons were retrieved at $2 \mathrm{~h}$ intervals progressively for $10 \mathrm{~h}$, scrubbed with a bristle brush, washed, dried and reweighed. The weight loss was taken as the difference between the initial and final weights of the coupons.

The surface coverage $(\theta)$ and inhibition efficiency $\left(\eta_{\mathrm{w}}\right)$ were determined by using the following equations:

$$
\begin{aligned}
& \theta=\frac{w^{0}-w}{W^{0}}, \\
& \eta_{\mathrm{w}}(\%)=\theta \times 100
\end{aligned}
$$

Where $w^{0}$ and $w$ are the weight loss without and with inhibitor, respectively. 
Extracts of Mint and Tea as Green Corrosion Inhibitors for Mild Steel

Table 1. Potentiodynamic polarization parameters for the corrosion of mild steel in $1.0 \mathrm{M} \mathrm{HCl}$ without and with different concentrations of the various inhibitors at $250 \mathrm{C}$.

\begin{tabular}{|c|c|c|c|c|c|c|c|}
\hline \multicolumn{2}{|c|}{$\begin{array}{l}\text { Conc., } \\
\text { ( ppm ) }\end{array}$} & $\begin{array}{c}\text { E }_{\text {corr }} \text { vs.SCE } \\
(\mathrm{mV})\end{array}$ & $\begin{array}{c}I_{\text {corr }} \\
\left.(\mathrm{mA} \mathrm{cm})^{-2}\right)\end{array}$ & $\begin{array}{c}\beta_{\mathrm{a}} \\
\left(\mathrm{mV} \operatorname{dec}^{-1}\right)\end{array}$ & $\begin{array}{c}\beta_{\mathrm{c}} \\
\left(\mathrm{mV} \operatorname{dec}^{-1}\right)\end{array}$ & $\boldsymbol{\Theta}$ & $\eta_{p}(\%)$ \\
\hline \multicolumn{2}{|c|}{ Blank } & -536.4 & 0.3141 & 122.2 & -152.9 & --- & -- \\
\hline \multirow{4}{*}{ 在 } & 100 & -531.0 & 0.0751 & 326.9 & -338.1 & 0.7609 & 76.1 \\
\hline & 300 & -579.5 & 0.0676 & 246.7 & -137.0 & 0.7847 & 78.5 \\
\hline & 500 & -588.4 & 0.0542 & 239.3 & -137.8 & 0.8274 & 82.7 \\
\hline & 700 & -535.4 & 0.0457 & 132.5 & -151.1 & 0.8545 & 85.45 \\
\hline \multirow{4}{*}{ 된 } & 100 & -575.0 & 0.0774 & 295.6 & -137.5 & 0.7535 & 75.35 \\
\hline & 300 & -593.8 & 0.0642 & 350.1 & -127.1 & 0.7956 & 79.56 \\
\hline & 500 & -584.6 & 0.0617 & 297.7 & -138.7 & 0.8035 & 80.35 \\
\hline & 700 & -506.7 & 0.0522 & 111.2 & -128.2 & 0.8338 & 83.38 \\
\hline \multirow{4}{*}{$\sum_{\infty}$} & 100 & -575.6 & 0.1013 & 287.5 & -126.7 & 0.6774 & 67.74 \\
\hline & 300 & -593.9 & 0.0898 & 295.4 & -139.1 & 0.7141 & 71.41 \\
\hline & 500 & -588.4 & 0.0783 & 268.6 & -130.4 & 0.7507 & 75.07 \\
\hline & 700 & -590.8 & 0.0611 & 345.1 & -125.1 & 0.8054 & 80.54 \\
\hline \multirow{4}{*}{$\sum$} & 100 & -520.5 & 0.1107 & 168.2 & -200.6 & 0.6475 & 64.75 \\
\hline & 300 & -529.3 & 0.1103 & 274.6 & -287.3 & 0.6488 & 64.88 \\
\hline & 500 & -529.3 & 0.0945 & 244.8 & -260.8 & 0.6991 & 69.91 \\
\hline & 700 & -510.4 & 0.0744 & 265.1 & -270.4 & 0.7631 & 76.31 \\
\hline
\end{tabular}

Table 2. Weight loss data for mild steel in 1.0M HCl without and with different concentrations of inhibitors at 25,35 and $450 \mathrm{C}$.

\begin{tabular}{|c|c|c|c|c|c|c|c|c|c|c|}
\hline \multirow{2}{*}{$\begin{array}{l}\text { Temp. } \\
\left({ }^{\circ} \mathrm{C}\right)\end{array}$} & \multirow{2}{*}{$\begin{array}{c}\text { Conc. of } \\
\text { inhibitor } \\
(\mathrm{ppm})\end{array}$} & \multicolumn{3}{|c|}{$25^{\circ} \mathrm{C}$} & \multicolumn{3}{|c|}{$35^{\circ} \mathrm{C}$} & \multicolumn{3}{|c|}{$45^{\circ} \mathrm{C}$} \\
\hline & & $\begin{array}{c}\mathrm{K} \times 10^{2} \\
\left(\mathrm{mg} / \mathrm{cm}^{2} . \mathrm{h}\right)\end{array}$ & $\theta$ & $\begin{array}{c}\eta_{w} \\
(\%)\end{array}$ & $\begin{array}{c}\mathrm{K} \times 10^{2} \\
\left(\mathrm{mg} / \mathrm{cm}^{2} . \mathrm{h}\right)\end{array}$ & $\Theta$ & $\begin{array}{c}\eta_{w} \\
(\%)\end{array}$ & $\begin{array}{c}\mathrm{K} \times 10^{2} \\
\left(\mathrm{mg} / \mathrm{cm}^{2} . \mathrm{h}\right)\end{array}$ & $\theta$ & $\begin{array}{c}\eta_{\mathrm{w}} \\
(\%)\end{array}$ \\
\hline \multirow{5}{*}{$x$} & 0.00 & 19.66 & ----- & ----- & 21.12 & ----- & ------ & 21.70 & ------ & ------ \\
\hline & 100 & 7.80 & 0.6067 & 60.67 & 8.56 & 0.5696 & 56.96 & 11.82 & 0.4616 & 46.16 \\
\hline & 300 & 7.20 & 0.6373 & 63.74 & 8.56 & 0.5730 & 57.30 & 10.68 & 0.5103 & 51.03 \\
\hline & 500 & 4.66 & 0.7681 & 76.81 & 7.31 & 0.6391 & 63.91 & 10.19 & 0.5352 & 53.52 \\
\hline & 700 & 3.52 & 0.8249 & 82.49 & 5.57 & 0.7210 & 72.10 & 8.48 & 0.6132 & 61.32 \\
\hline \multirow{5}{*}{ 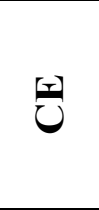 } & 0.00 & 19.66 & ----- & ----- & 21.12 & ----- & ------ & 21.70 & ----- & ------ \\
\hline & 100 & 7.97 & 0.5977 & 59.77 & 13.18 & 0.3462 & 34.62 & 14.51 & 0.3344 & 33.44 \\
\hline & 300 & 7.46 & 0.6244 & 62.44 & 8.71 & 0.5563 & 55.63 & 10.15 & 0.5331 & 53.31 \\
\hline & 500 & 4.92 & 0.7524 & 75.24 & 8.11 & 0.5912 & 59.12 & 9.17 & 0.5800 & 58.00 \\
\hline & 700 & 4.05 & 0.7966 & 79.66 & 7.35 & 0.6320 & 63.20 & 8.14 & 0.6286 & 62.86 \\
\hline \multirow{5}{*}{$\sum_{\infty}$} & 0.00 & 19.66 & ----- & ----- & 21.12 & ----- & ------ & 21.70 & ------ & ----- \\
\hline & 100 & 8.75 & 0.5584 & 55.84 & 11.21 & 0.4325 & 43.25 & 12.58 & 0.4230 & 42.30 \\
\hline & 300 & 8.37 & 0.5773 & 57.73 & 9.89 & 0.5178 & 51.78 & 11.21 & 0.4868 & 48.68 \\
\hline & 500 & 5.91 & 0.7035 & 70.35 & 7.95 & 0.6206 & 62.06 & 8.67 & 0.6054 & 60.54 \\
\hline & 700 & 4.98 & 0.7509 & 75.09 & 7.65 & 0.6275 & 62.75 & 8.41 & 0.6198 & 61.98 \\
\hline \multirow{5}{*}{$\sum_{3}$} & 0.00 & 19.66 & ----- & ----- & 21.12 & ----- & ------ & 21.70 & ----- & ------ \\
\hline & 100 & 9.62 & 0.5180 & 51.80 & 10.27 & 0.4959 & 49.59 & 14.68 & 0.4177 & 41.77 \\
\hline & 300 & 9.02 & 0.5489 & 54.89 & 9.28 & 0.5447 & 54.47 & 10.11 & 0.5382 & 53.82 \\
\hline & 500 & 8.33 & 0.5845 & 58.45 & 8.60 & 0.5794 & 57.94 & 9.52 & 0.5621 & 56.21 \\
\hline & 700 & 5.19 & 0.7435 & 74.35 & 7.58 & 0.6254 & 62.54 & 8.33 & 0.6221 & 62.21 \\
\hline
\end{tabular}


Table 3. Adsorption isotherms models of the inhibitors with values of $\mathbf{R} 2$.

\begin{tabular}{|c|c|c|c|c|c|}
\hline Inhibitor & $\begin{array}{c}\text { Temp. } \\
\left({ }^{\circ} \mathrm{k}\right)\end{array}$ & $\begin{array}{l}\mathrm{K}_{\mathrm{ads}} \\
\left(\mathrm{M}^{-1}\right)\end{array}$ & $\begin{array}{c}\Delta \mathrm{G}_{\text {ads }}^{\mathrm{o}} \\
(\mathrm{KJ} / \mathrm{mol})\end{array}$ & $\begin{array}{c}\Delta \mathrm{S}_{\text {ads }}^{\mathrm{o}} \\
\left(\mathrm{J} / \mathrm{mol} .^{\mathrm{o}} \mathrm{k}\right)\end{array}$ & $\begin{array}{c}\Delta \mathrm{H}^{\mathrm{o}} \text { ads } \\
(\mathrm{KJ} / \mathrm{mol})\end{array}$ \\
\hline \multirow{3}{*}{ TEX } & 298 & 0.126 & -21.94 & 48.12 & \multirow{3}{*}{-7.60} \\
\hline & 308 & 0.118 & -27.52 & 66.84 & \\
\hline & 318 & 0.104 & -31.91 & 81.55 & \\
\hline \multirow{3}{*}{$\mathbf{C E}$} & 298 & 0.118 & -30.78 & 17.07 & \multirow{3}{*}{-25.70} \\
\hline & 308 & 0.069 & -31.47 & 19.38 & \\
\hline & 318 & 0.062 & -33.53 & 26.30 & \\
\hline \multirow{3}{*}{ SM } & 298 & 0.104 & -21.48 & 37.11 & \multirow{3}{*}{-10.41} \\
\hline & 308 & 0.093 & -22.90 & 38.54 & \\
\hline & 318 & 0.080 & -22.22 & 39.60 & \\
\hline \multirow{3}{*}{ LM } & 298 & 0.161 & -22.54 & 11.21 & \multirow{3}{*}{-19.20} \\
\hline & 308 & 0.141 & -22.96 & 12.64 & \\
\hline & 318 & 0.098 & -23.75 & 15.29 & \\
\hline
\end{tabular}

Table 4. Standard thermodynamic parameters of adsorption on mild steel surface in 1.0M HCl containing different concentrations of the inhibitors.

\begin{tabular}{|c|c|c|c|c|}
\hline Inhibitor & $\begin{array}{l}\text { Inhibitor Conc. } \\
\text { (ppm) }\end{array}$ & $\begin{array}{c}\mathrm{E}_{\mathrm{a}} \\
\left(\mathrm{kJ} \mathrm{mol}^{-1}\right) \\
\end{array}$ & $\begin{array}{c}\Delta \mathrm{H}^{*} \\
\left(\mathrm{~kJ} \mathrm{~mol}^{-1}\right)\end{array}$ & $\begin{array}{c}\Delta \mathrm{S}^{*} \\
\left(\mathrm{~J} \mathrm{~mol}^{-1} \mathrm{~K}^{-1}\right)\end{array}$ \\
\hline Blank & 0.00 & 03.92 & 11.22 & -67.75 \\
\hline \multirow{4}{*}{ TEX } & 100 & 16.25 & 31.40 & -11.74 \\
\hline & 300 & 15.53 & 30.71 & -14.69 \\
\hline & 500 & 30.87 & 53.24 & 55.95 \\
\hline & 700 & 34.64 & 59.40 & 73.05 \\
\hline \multirow{4}{*}{$\mathbf{C E}$} & 100 & 23.75 & 41.58 & 23.86 \\
\hline & 300 & 25.06 & 43.60 & 28.46 \\
\hline & 500 & 24.64 & 44.53 & 27.86 \\
\hline & 700 & 27.79 & 49.41 & 42.11 \\
\hline \multirow{4}{*}{ SM } & 100 & 14.34 & 28.39 & -19.79 \\
\hline & 300 & 11.52 & 24.70 & -32.88 \\
\hline & 500 & 06.32 & 18.05 & -56.82 \\
\hline & 700 & 20.67 & 39.21 & 10.06 \\
\hline \multirow{4}{*}{$\mathbf{L M}$} & 100 & 16.51 & 31.00 & -10.68 \\
\hline & 300 & 04.50 & 14.84 & -65.25 \\
\hline & 500 & 05.20 & 16.07 & -62.08 \\
\hline & 7000 & 18.78 & 336.33 & 0.83 \\
\hline
\end{tabular}




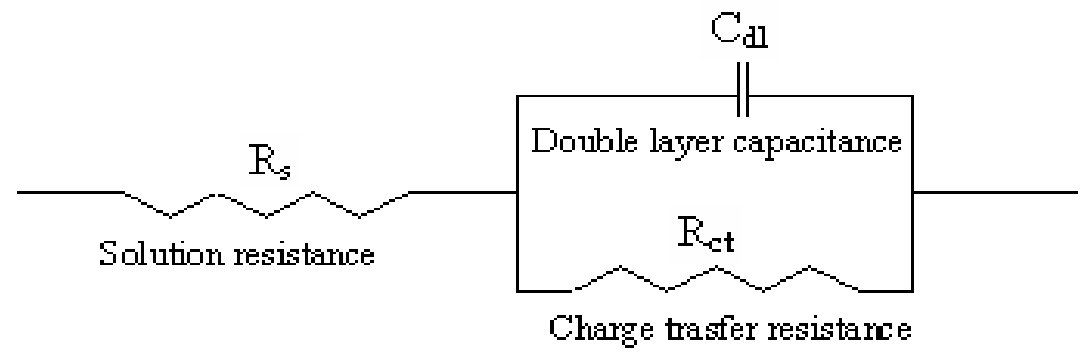

Fig. 1. Electrical equivalent circuit used for modeling the interface steel / 1.0M HCl solution in the absence and in the presence of the prepared natural products.

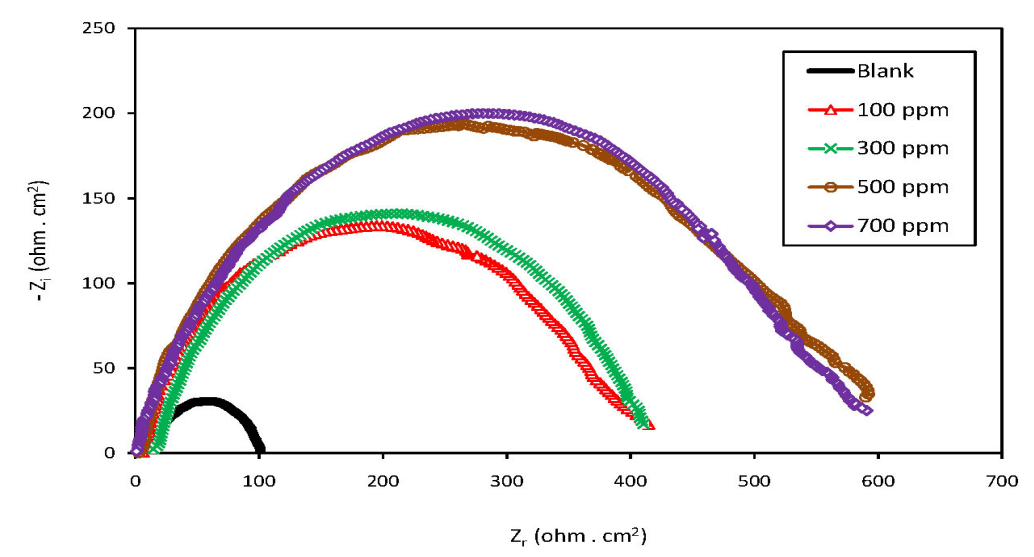

Fig. 2. Nyquist plots of mild steel in 1.0 M HCl without and with different concentrations of inhibitor TEX at 250C.

Fig. 3. Nyquist plots of mild steel in 1.0 M HCl without and with different concentrations of inhibitor $\mathrm{CE}$ at $250 \mathrm{C}$.
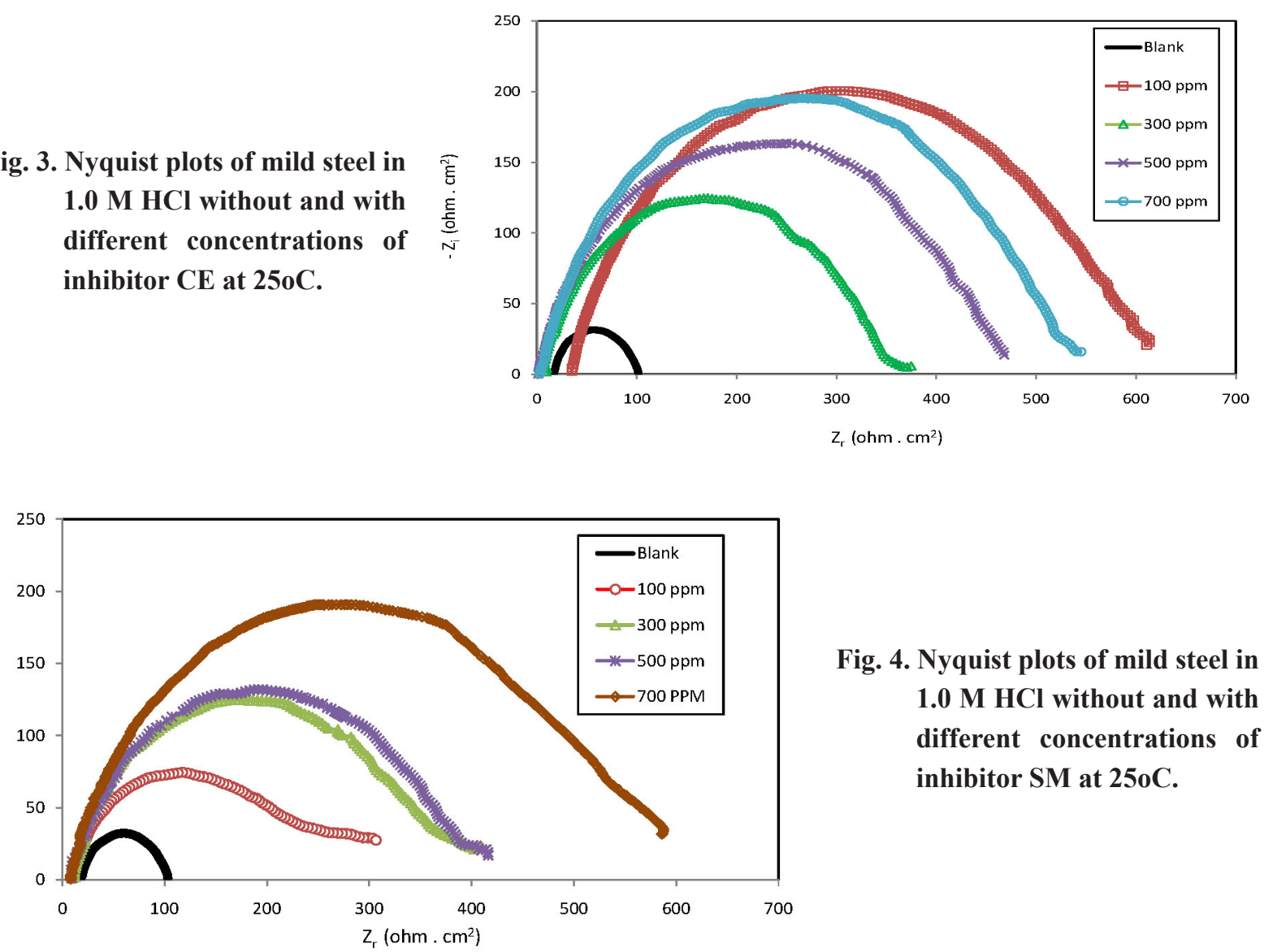

Fig. 4. Nyquist plots of mild steel in 1.0 M HCl without and with different concentrations of inhibitor SM at $250 \mathrm{C}$. 

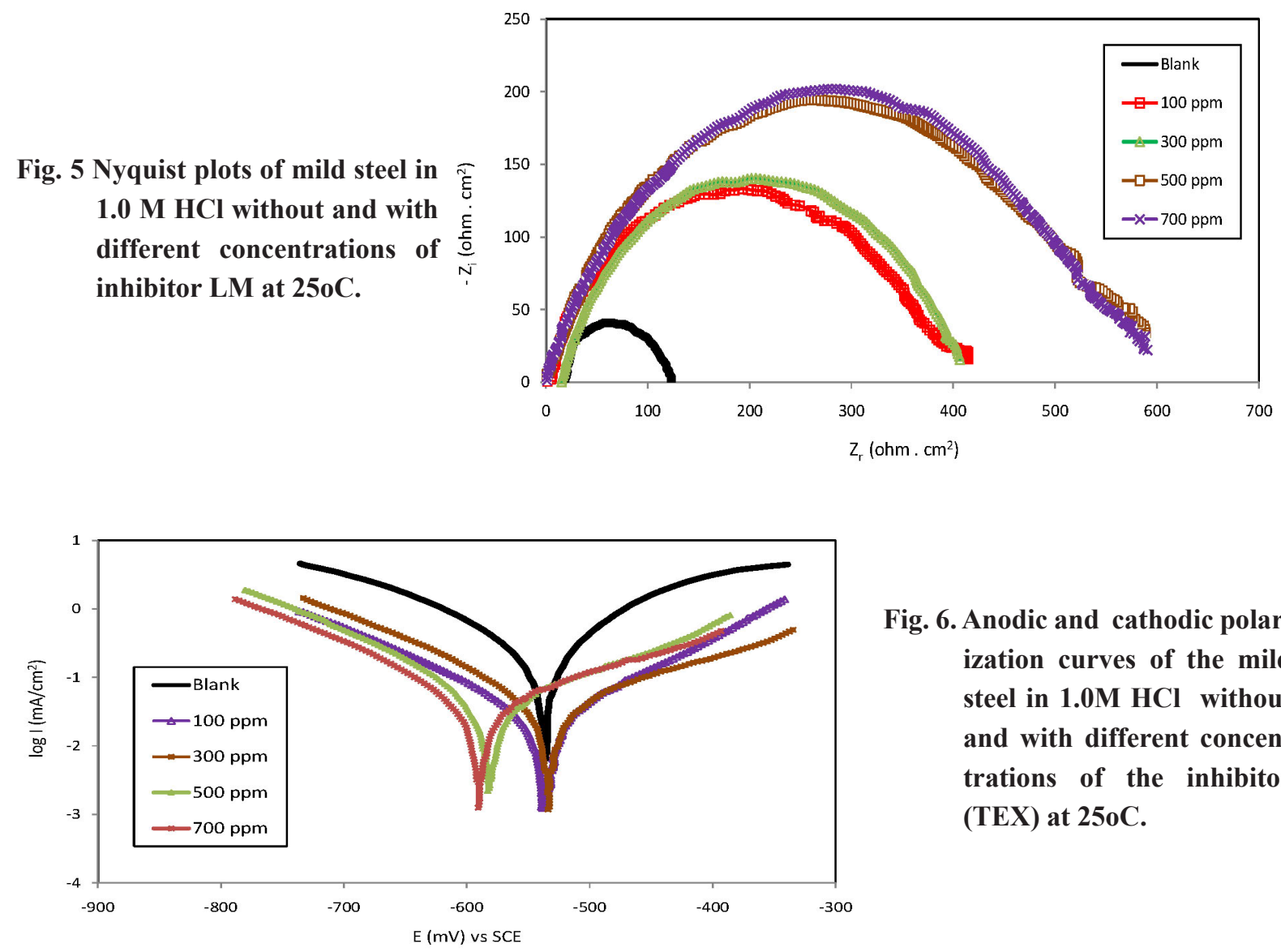

Fig. 6. Anodic and cathodic polarization curves of the mild steel in $1.0 \mathrm{M} \mathrm{HCl}$ without and with different concentrations of the inhibitor (TEX) at 25oC.

Fig. 7. Anodic and cathodic polarization curves of the mild steel in 1.0M HCl without and with different concentrations of the inhibitor (CE) at $250 \mathrm{C}$.
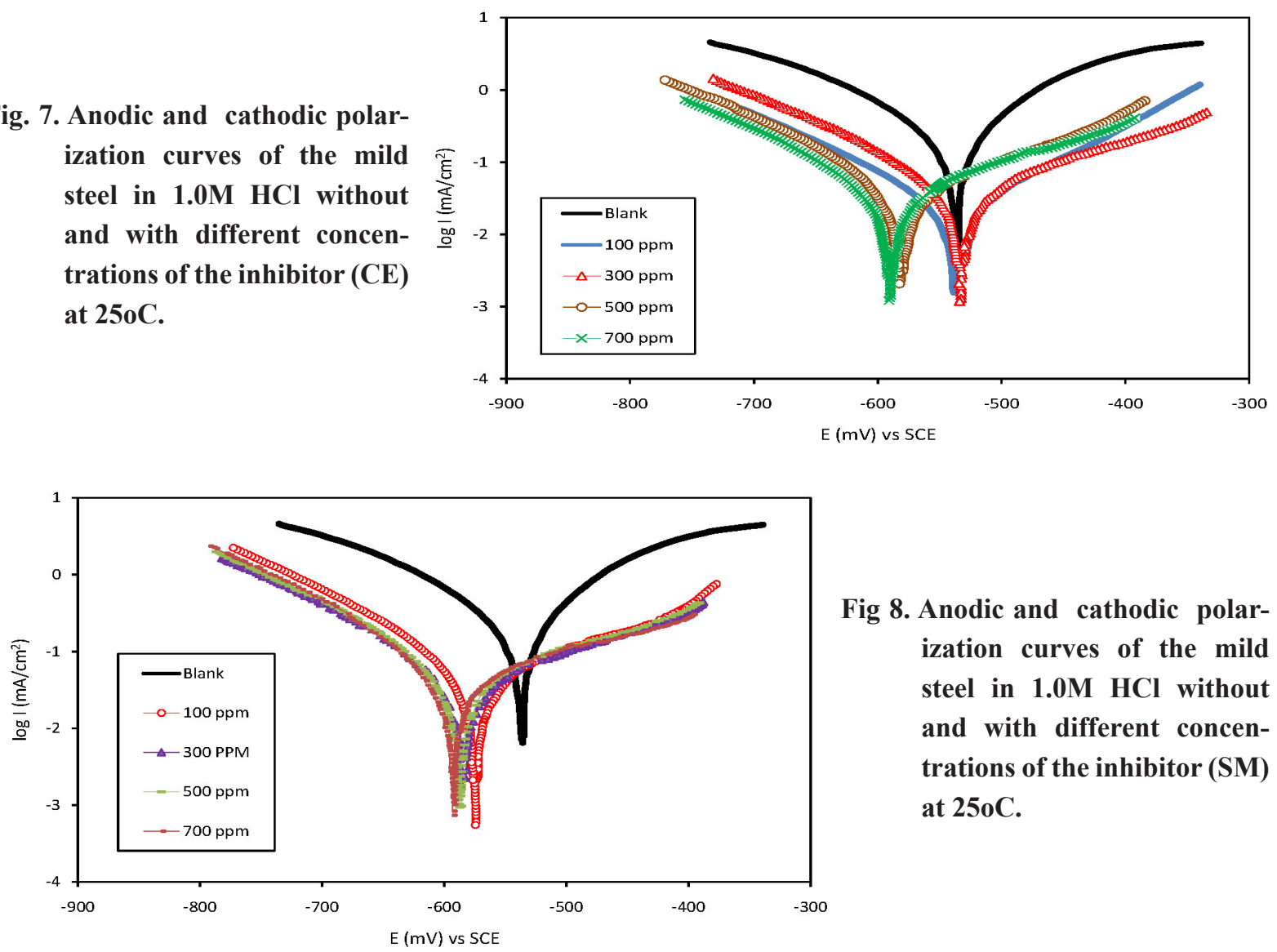

Fig 8. Anodic and cathodic polarization curves of the mild steel in $1.0 \mathrm{M} \mathrm{HCl}$ without and with different concentrations of the inhibitor (SM) at $250 \mathrm{C}$. 
Fig. 9. Anodic and cathodic polarization curves of the mild steel in 1.0M $\mathrm{HCl}$ without and with different concentrations of the inhibitor (LM) at 25oC.
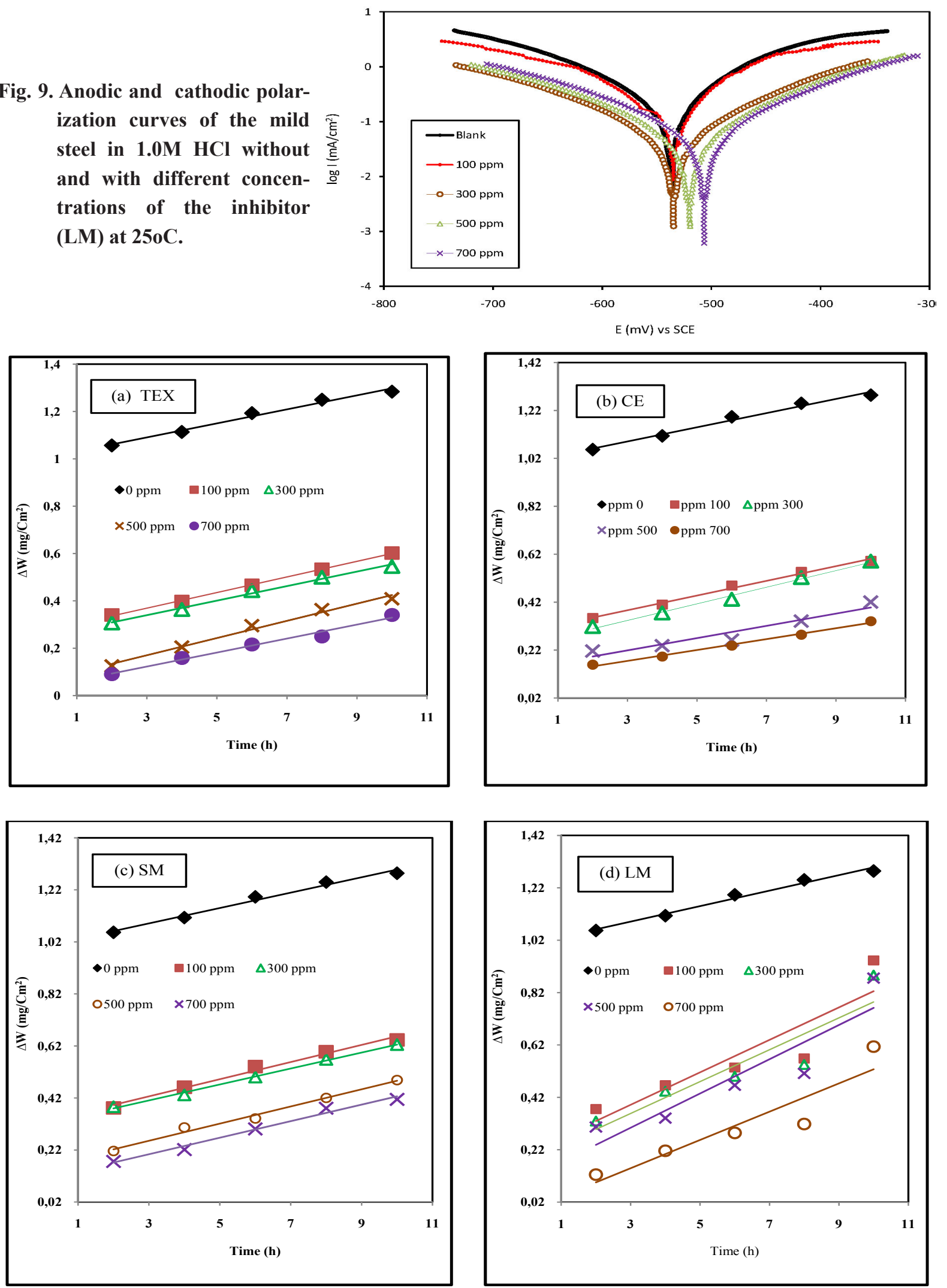

Fig. 10. Variation of weight loss with exposure time for mild steel immersed in $1.0 \mathrm{M} \mathrm{HCl}$ at different concentrations of (a) TEX, (b) CE, (c) SM and (d) LM at 250C. 


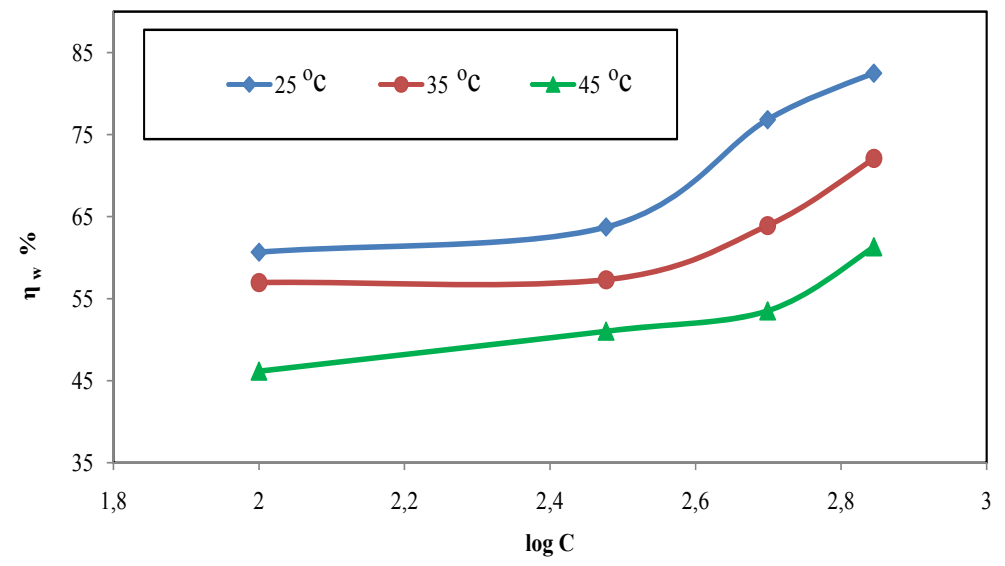

Fig. 11. Effect of temperature on the inhibition efficiency obtained by weight loss method for mild steel in $1.0 \mathrm{M} \mathrm{HCl}$ in the presence of different concentrations of TEX.

Fig. 12. Effect of temperature on the inhibition efficiency obtained by weight loss method for mild steel in 1.0 M HCl in the presence of different concentrations of $\mathbf{C E}$.
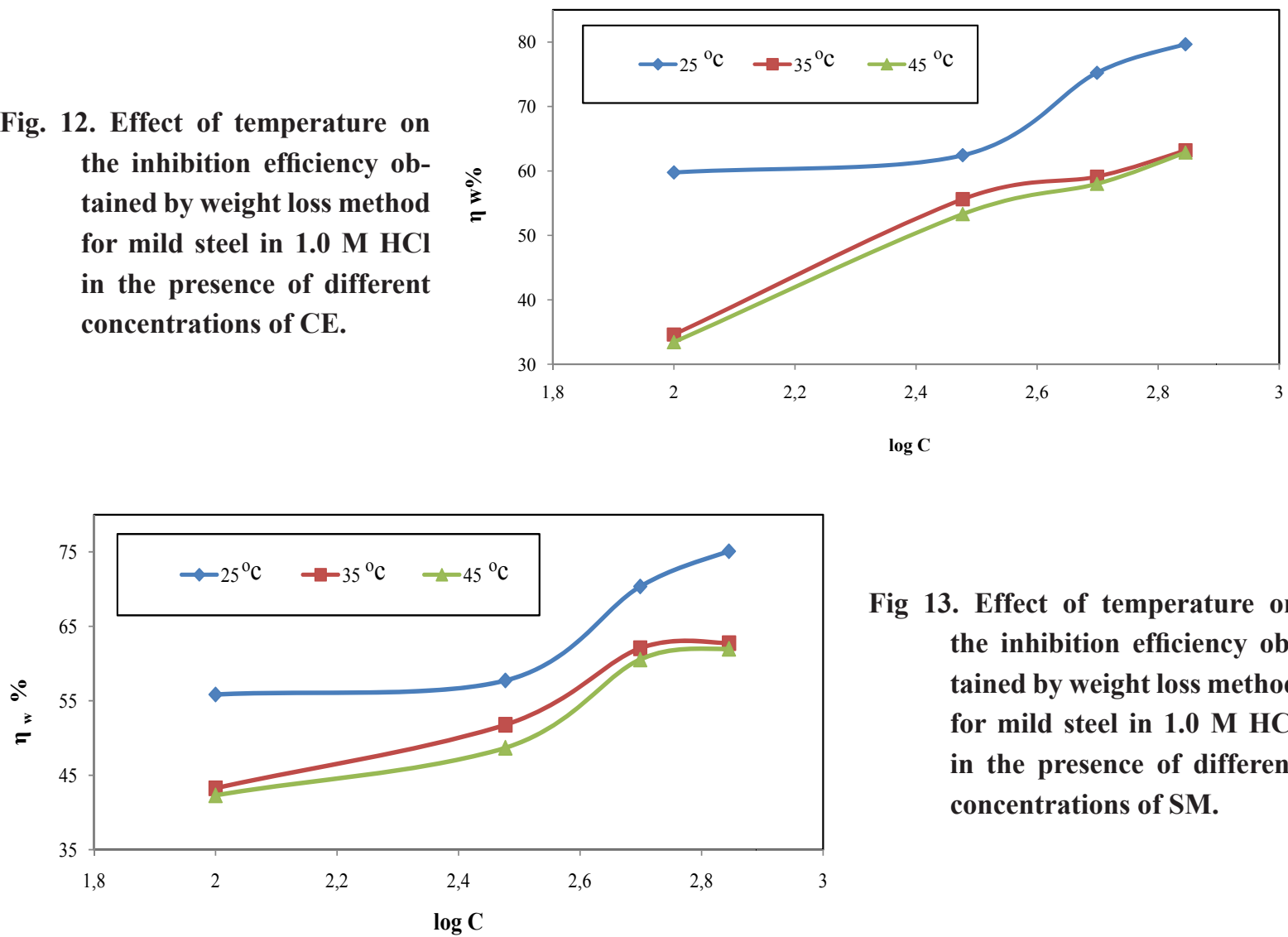

Fig 13. Effect of temperature on the inhibition efficiency obtained by weight loss method for mild steel in $1.0 \mathrm{M} \mathrm{HCl}$ in the presence of different concentrations of SM.

Fig. 14. Effect of temperature on the inhibition efficiency obtained by weight loss method for mild steel in 1.0 M HCl in the presence of different concentrations of $\mathbf{L M}$.

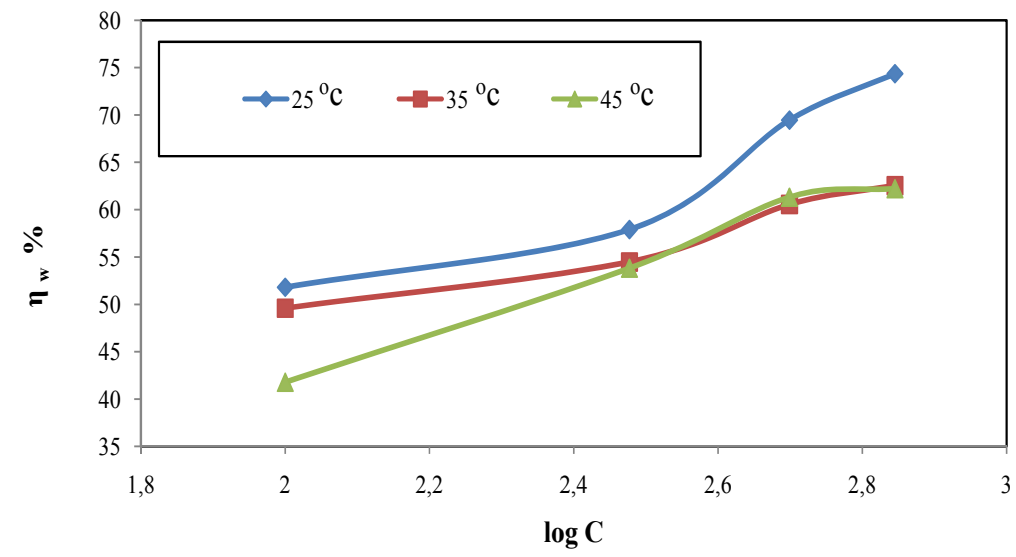




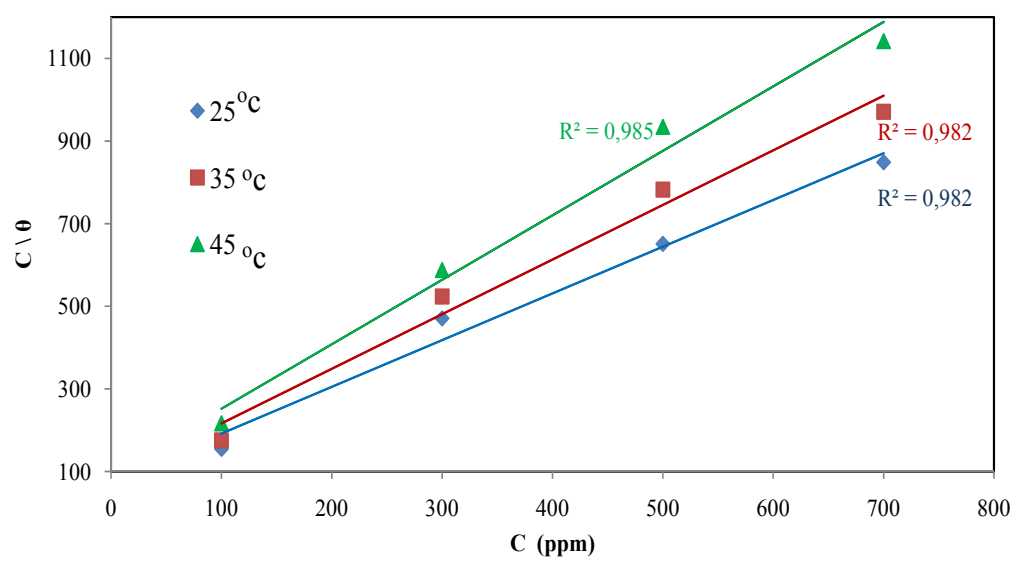

Fig. 15. Langmuir's adsorption plots for the mild steel in $\mathbf{1 . 0}$ M HCI of TEX at different temperatures.

Fig. 16. Langmuir's adsorption plots for the mild steel in $\mathbf{1 . 0}$ M HCl of CE at different temperatures..
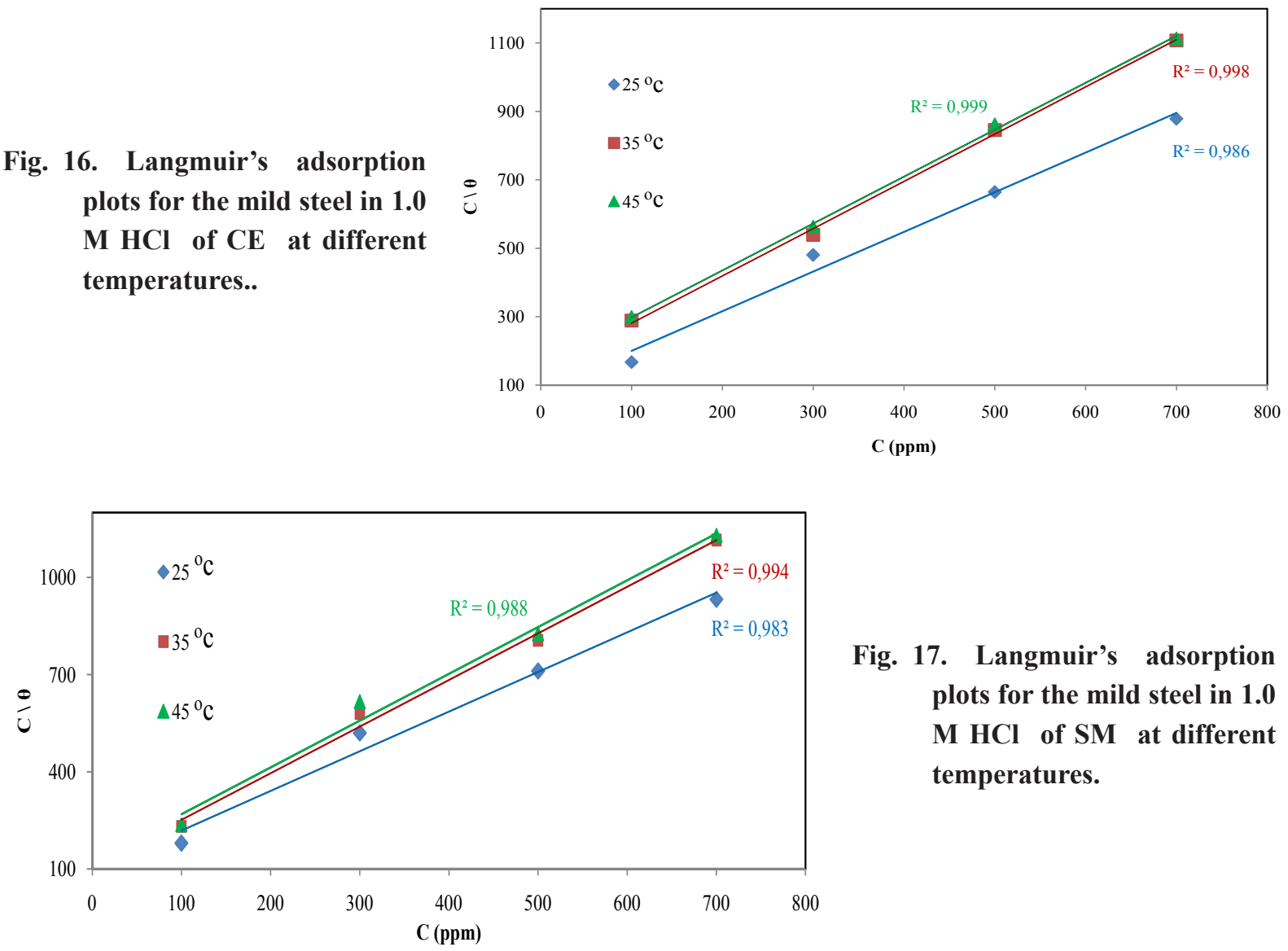

Fig. 17. Langmuir's adsorption plots for the mild steel in $\mathbf{1 . 0}$ M HCl of SM at different temperatures.

Fig. 18. Langmuir's adsorption plots for the mild steel in $\mathbf{1 . 0}$ $\mathrm{M} \mathrm{HCl}$ of $\mathrm{LM}$ at different temperatures.

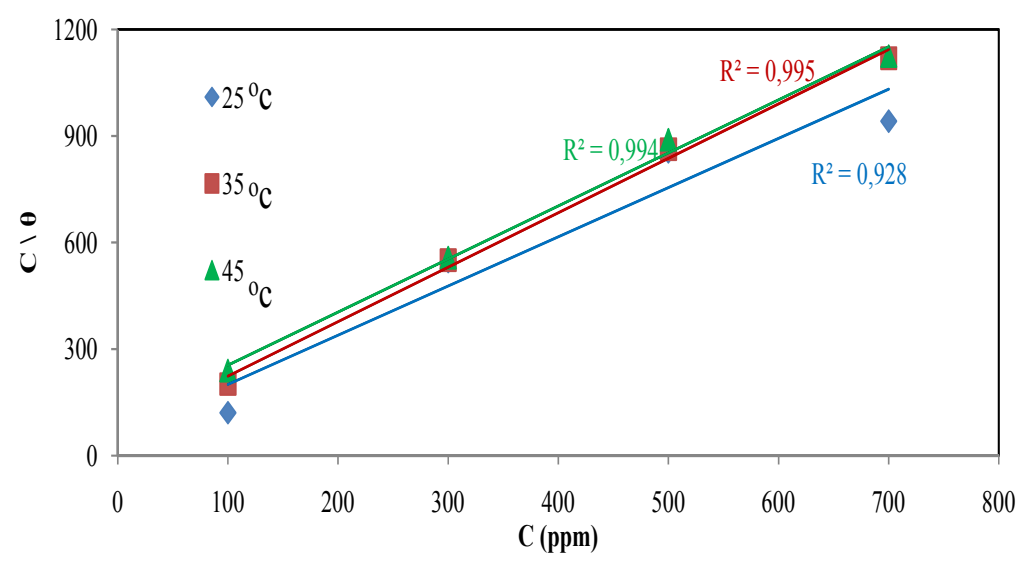




\section{RESULTS AND DISCUSSION}

\subsection{EIS Measurement:}

The corrosion behavior of steel in $1.0 \mathrm{M} \mathrm{HCl}$ solution in the absence and in the presence of the natural products (CE, LM, SM, and TEX) was investigated by EIS method at $25^{\circ} \mathrm{C}$. The impedance spectra of different Nyquist plots were analyzed by fitting the experimental data to a simple equivalent circuit model as shown in Figure 1 which includes the solution resistant $\mathrm{R}_{\mathrm{s}}$ and the double layer capacitance $\mathrm{C}_{\mathrm{dl}}$ which is placed in parallel to the charge transfer resistance $\mathrm{R}_{\mathrm{ct}}$.

Impedance spectra for mild steel in $1.0 \mathrm{M} \mathrm{HCl}$ in the absence and in the presence of different concentrations of (TEX, CE, SM, and LM) are shown in the form of Nyquist plotsin Figures (2-5). The Nyquist plots are regarded as one part of a semicircle. The impedance diagram shows the same behavior (one capacitive loop); however, the diameter of this capacitive loop increases with the order of $700 \mathrm{ppm}>500$ $\mathrm{ppm}>300 \mathrm{ppm}>100 \mathrm{ppm}$ of natural products inhibitors.

The main parameters deduced from the analysis of Nyquist diagrams are the resistance of charge transfer $\mathrm{R}_{\mathrm{ct}}$ and the capacitance of double layer $C_{d 1}$. The charge transfer resistance values $\left(\mathrm{R}_{\mathrm{ct}}\right)$ are calculated from the difference in impedance at lower and higher frequencies, as suggested by Haruyama and Tsuru [40]. To obtain the double-layer capacitance $\left(\mathrm{C}_{\mathrm{dl}}\right)$, the frequency at which the imaginary component of the impedance at maximum $f_{\max }$ is obtained and the $\mathrm{C}_{\mathrm{dl}}$ values are calculated from the following equation [41]:

$$
f_{\max }=1 /\left(2 \pi \mathrm{C}_{\mathrm{dl}} \mathrm{R}_{\mathrm{ct}}\right)
$$

The inhibition efficiency $\eta_{z}(\%)$ is calculated using charge transfer resistance as follows [42]:

$$
\left.\eta_{\mathrm{Z}} \%=\left\{\left(\mathrm{R}_{\mathrm{ct}(\mathrm{inh})}\right)-\mathrm{R}_{\mathrm{ct}}\right) / \mathrm{R}_{\mathrm{ct}(\mathrm{inh})}\right\} \times 100
$$

Where, $\mathrm{R}_{\mathrm{ct}}$ and $\mathrm{R}_{\mathrm{ct}(\mathrm{inh})}$ are the charge transfer resistance values in the absence and in the presence of inhibitors for steel in $1.0 \mathrm{M} \mathrm{HCl}$, respectively; The $\mathrm{R}_{\mathrm{ct}}$ values increased, whereas the $\mathrm{C}_{\mathrm{dl}}$ values decreased. The decrease in $\mathrm{C}_{\mathrm{dl}}$ value is due to the desorption of inhibitors on the metal surface [43]. And may be arise from a decrease in local dielectric constant and/or an increase in the thickness of the electrical double layer, which suggested that the inhibitors molecules acted by adsorption at the metal/solution interface. Addition of plants extracts inhibitors provided lower $C_{\mathrm{dl}}$ values, probably as a consequence of replacement of water molecules by inhibitor molecule at the electrode surface. Also the inhibitor molecules may reduce the capacitance by increasing the double layer thickness according to the Helmholtz model [44]:

$$
\delta_{o r g}=\frac{\varepsilon \varepsilon_{0} A}{C_{d l}}
$$

Where, $\delta_{\text {org }}$ is the thickness of the protective layer, $\varepsilon$ is the dielectric constant of the medium, $\varepsilon_{\mathrm{o}}$ is the vacuum permittivity and $A$ is the electrode surface area and $C_{d l}$ values always smaller in the presence of the inhibitors than in its absence, which may be resulted from the effective adsorption of the inhibitors. This fact suggests that the inhibitors may first be adsorbed on the steel surface and cover some sites of the electrode surface; these layers protect steel surface.

\section{Polarization studies}

Polarization curves obtained for mild steel at various concentrations of (TEX, CE, SM, and LM) in aerated solutions are shown in Figures (6-9). The extrapolation of Tafel straight lines of charge transfer controlled corrosion reaction gives the corrosion current density, $\mathrm{I}_{\text {corr }}$ at corrosion potential, $\mathrm{E}_{\text {corr }}$. This method was based on the electrochemical theory of corrosion processes developed by Wagner and Traud [45]. The inhibition efficiency $\eta_{p} \%$ was calculated using the following equation:

$$
\eta_{\mathrm{p}}(\%)=\left(\frac{{ }_{\text {corr }}-I_{\text {corr }(\text { inh })}}{I_{\text {corr }}}\right) \times 100
$$

where, $I_{\text {corr }}$ and $I_{\text {corr(inh) }}$ are the corrosion current densities in absence and presence of inhibitors, respectively, which are determined by extrapolation of cathodic and anodic Tafel lines to the respective free corrosion potential.

The degree of surface coverage $(\Theta)$ was calculated by the following equation:

$$
\Theta=\left(\frac{\mathrm{I}_{\mathrm{corr}}-\mathrm{I}_{\operatorname{corr}(\mathrm{inh})}}{\mathrm{I}_{\mathrm{corr}}}\right)
$$

The electrochemical parameters, namely corrosion current density $\left(\mathrm{i}_{\text {corr }}\right)$, corrosion potential $\left(\mathrm{E}_{\text {corr }}\right)$, anodic Tafel slope $(\beta \mathrm{a})$ and cathodic Tafel slope $(\beta c)$, associated with polarization measurements and the inhibition efficiency $\left(\eta_{\mathrm{p}}\right)$ at different 
inhibitor concentrations are listed in Table 1 . The corrosion rate is inhibited by the addition of the inhibitors (plant extract) in both cathodic and anodic reactions. So; they act as mixed type inhibitors.

\subsection{Weight Loss Measurements:}

\subsubsection{Effect of Inhibitor Concentration.}

The corrosion rate of mild steel, in the absence and presence of the four inhibitors (TEX, $C E$, $S M$, and $L M)$ at 25,35 and $45^{\circ} \mathrm{C}$, was studied using weight loss technique. Table 2 shows the calculated values of corrosion rate $\left(\mathrm{mg}_{\mathrm{cm}} \mathrm{cm}^{-}\right.$ $\left.{ }^{2} \cdot h^{-1}\right)$; inhibition efficiency percent $\left(\eta_{w} \%\right)$ at different inhibitors concentrations was calculated by the equation[46]:

$$
\eta_{\mathrm{w}}(\%)=\left[1-\left(\frac{\mathrm{K}_{\mathrm{inh}}}{\mathrm{K}}\right)\right] \times 100
$$

Where $\mathrm{K}_{\text {inh }}$ and $\mathrm{K}$ are the corrosion rates of the steel in absence and presence of different concentrations of the inhibitors (plants extracts). As the concentration of inhibitor increases, the inhibition efficiency increases to give maximum value at concentration $700 \mathrm{ppm}$. The corrosion inhibition efficiencies $\left(\eta_{\mathrm{w}} \%\right)$ of the tested inhibitors which are calculated from weight loss technique at different concentrations showed that there is a direct proportionality relationship between the inhibitor concentration and corrosion inhibition efficiency. The effect of increasing concentrations of the inhibitors on the weight loss of steel sheets versus time curves at $25^{\circ} \mathrm{C}$ are shown in Figure 10. It is obvious that the weight loss of steel in the presence of the inhibitors varies linearly with time, and is much lower than that obtained in the blank solution. The linearity obtained indicates the absence of insoluble surface film during corrosion and the inhibitors are firstly adsorbed on the metal surface and thereafter, impede the corrosion process. These results lead to conclusion that, the natural products under investigation are fairly efficient as inhibitors for mild steel in $1.0 \mathrm{M} \mathrm{HCl}$. It was found that the inhibition efficiencies decrease in the following order: $\mathrm{TEX}>\mathrm{CE}>\mathrm{SM}>\mathrm{LM}$ at $25^{\circ} \mathrm{C}$.

\subsubsection{Effect of Temperature.}

The corrosion behavior and corrosion inhibition of mild steel in $1.0 \mathrm{M} \mathrm{HCl}$ solution at different temperatures were carried out at the range of $25-45^{\circ} \mathrm{C}$ at different concentrations during $10 \mathrm{~h}$ immersion time. As shown in Figures (11-14) the inhibition efficiency decreases with increasing temperature as a result of the desorption of the adsorbed inhibitors' molecules from the metal surface physical adsorption which is a reversible process which is greatly affected by temperature and can be represented by the following equation:

$$
\begin{gathered}
{\mathrm{M}-\mathrm{I}_{(\mathrm{ads})}} \leftrightarrow{ }^{\Delta} \quad \mathrm{M}+\mathrm{I}, \\
\text { where } \quad \mathrm{M}=\text { metal and } \mathrm{I}=\text { inhibitor. }
\end{gathered}
$$

The variation of inhibition efficiency $\left(\eta_{w}\right)$ with the concentrations of different plant extracts (TEX, CE, SM, and LM) in acid medium has Sshaped adsorption isotherms, which is characterized by an initial ascending part indicating a formation of a mono-layer adsorbate film on the mild steel surface.

\section{Adsorption isotherm}

Corrosion inhibitors effect the process of adsorption of ions or molecules over metal surfaces. They reduce the corrosion rate, mainly by increasing or decreasing the anodic and/or cathodic reactions, decreasing the diffusion rate for reactants to the surface of the metal and the electrical resistance of the metal surface [47]. Adsorption depends mainly on the charge and the nature of the metal surface, electronic characteristics of the metal surface, adsorption of solvents and other ionic species, as well as the electrochemical potential at the solution interface.

The adsorption of organic adsorbate on the surface of metal is regarded as aquasi-substitutional adsorption process between the organic compound in the aqueous phase (Org.)aq and the water molecules adsorbed at the metal surface $\left(\mathrm{H}_{2} \mathrm{O}\right)$ ads[48].

$$
\operatorname{Org}_{\mathrm{aq}_{+}} x\left(\mathrm{H}_{2} \mathrm{O}\right)_{\mathrm{ads}} \Leftrightarrow \operatorname{Org}_{\mathrm{ads}+} x\left(\mathrm{H}_{2} \mathrm{O}\right)_{\mathrm{aq}}(10)
$$

Where $x$ is the number of water molecules replaced by one organic inhibitor molecule.To clarify the nature of adsorption of plant extracts on the mild steel surface, the theoretical fitting of different isotherms, namely Langmuir [49], Flory-Huggins [50], the kinetic-thermodynamic [51] and Freundlich [52] models were investigated in $1.0 \mathrm{M} \mathrm{HCl}$ solutions cited in Table 3. The correlation coefficient $\left(\mathrm{R}^{2}\right)$ was used to choose the isotherm that well fit with the experimental 
data which was the closest to unity.

The adsorption of natural products on the mild steel surface in $\mathrm{HCl}$ solution obeys the Langmuir adsorption isotherm $\left(\mathrm{C} / \theta=1 / k_{\text {ads }}+C\right)$ according to their greatest correlation coefficient $\left(\mathrm{R}^{2}\right)$, where $k$ is the equilibrium binding constant of the adsorption process and $C$ represents the inhibitor concentration and is the surface coverage. The best fitted straight line is obtained from the plot of $C / \theta$ against $C$ obtained from weight loss measurements, as shown in Figures (15-18).

The adsorptive equilibrium constant $\left(K_{\text {ads }}\right)$ values are listed in Table 4. It is known that $K_{\text {ads }}$ denotes to the strength between adsorbate and adsorbent. Large values of $K_{\text {ads }}$ imply more adsorption and hence better inhibition efficiency $[53,54]$. Therfore, the physical adsorption may occur due to the electrostatic attraction between the plant extract (inhibitor) and the surface of mild steel.

The relation between equilibrium binding constant of adsorption $\left(K_{\text {ads }}\right)$ and the standard free energy $\left(\Delta \mathrm{G}^{\mathrm{o}}{ }_{\mathrm{ads}}\right)$ is given by the following equation [48]:

$$
K_{\text {ads }}=\frac{1}{55.5} \exp \left(\frac{-\Delta G^{0} a d s}{R T}\right)
$$

Where, $\mathrm{R}$ is the universal gas constant, $\mathrm{T}$ is the absolute temperature and 55.5 is the concentration of water expressed in molar.

The calculated values of $\Delta \mathrm{G}^{\circ}$ ads are ranging between -21.48 and -33.53 suggesting that the nature of the inhibitor adsorption may obey both physisorption and chemisorptions [55] whereas the negative sign indicates a spontaneous interaction of the inhibitor molecule with the corroding metal surface.

Generally, the values of $\Delta \mathrm{G}_{\text {ads }}$ up to $-20 \mathrm{~kJ}-$ $\mathrm{mol}^{-1}$ are considered as physical adsorption while chemisorption is around $-40 \mathrm{kJmol}^{-1}$ as a result of sharing or transfer of electrons from inhibitor to the metal surface to form a coordinate type of bond $[56,57]$.

The standard adsorption heat content change was calculated according to the Van't Hoff equation [58]:

$$
\ln K_{a d s}=-\left(\frac{-\Delta H^{0} a d s}{R T}\right)+\text { const. }
$$

Where $\Delta \mathrm{H}^{\circ}$ ads and $K_{\text {ads }}$ are the standard adsorption enthalpy change and adsorptive equilibrium constant, respectively. $\Delta \mathrm{H}^{\mathrm{o}}$ ads values can be obtained by plotting - $\Delta{H^{\circ}}_{\text {ads }} \mathrm{l} / \mathrm{T}$ yielded straight line with slope equals to

$R$. The negative values of $\Delta \mathrm{H}^{\mathrm{o}}$ ads show that the adsorption of the inhibitors is an exothermic process, indicating that, the inhibition efficiency decreases with the temperature increasing, and their values are around -7.60 and $-25.70 \mathrm{kj} \mathrm{mol}^{-1}$ indicated that physical adsorption take place.

Standard entropy change of inhibitor adsorption $\left(\Delta \mathrm{S}_{\text {ads }}^{\circ}\right)$ can be calculated using the following equation[59]:

$$
\Delta \mathrm{G}_{\text {ads }}^{\mathrm{o}}=\Delta \mathrm{H}^{\mathrm{o}}{ }_{\mathrm{ads}}-\mathrm{T} \Delta \mathrm{S}_{\text {ads }}^{\mathrm{o}}
$$

It is clear that from results (as shown in table 4) that $\Delta \mathrm{S}^{\mathrm{o}}{ }_{\text {ads }}$ has positive values which increase as the temperature increase indicating that the adsorption process passes from less orderly to a more random arrangement [60].

\section{Activation parameters}

The apparent activation energies $\left(E_{a}\right)$ for the corrosion process of mild steel sample in $1.0 \mathrm{M}$ $\mathrm{HCl}$ solution without and with different concentrations of plants extracts (inhibitors) at 25, 35, and $45^{\circ} \mathrm{C}$ are calculated from Arrhenius equation [61]:

$$
\log k=\log A-\frac{E_{a}}{2.303 R T}
$$

Where $k$ is the corrosion rate determined from weight loss measurements, $\mathrm{E}_{\mathrm{a}}$ is the apparent activation energy, $\mathrm{A}$ is the Arrhenius constant, $\mathrm{R}$ is the universal gas constant and $\mathrm{T}$ is the absolute temperature. The change in enthalpy and entropy of activation values $\left(\Delta \mathrm{H}^{*}, \Delta \mathrm{S}^{*}\right)$ are calculated from the transition state theory $[62,63]$.

$$
\ln \left(\frac{K}{\mathrm{~T}}\right)=\left[\ln \left(\frac{\mathrm{R}}{\mathrm{Nh}}\right)+\left(\frac{\Delta \mathrm{S}^{*}}{\mathrm{R}}\right)\right]-\left(\frac{-\Delta \mathrm{H}^{*}}{\mathrm{RT}}\right)
$$

Where $\mathrm{h}$ is the Planck's constant, $\mathrm{N}$ is the Avogadro's number, $\mathrm{T}$ is the absolute temperature and $\mathrm{R}$ is the universal gas constant, $k$ is the corrosion rate.

The values of $\Delta \mathrm{H}^{*}$ and $\Delta \mathrm{S}^{*}$ are calculated from the slope and intercept, respectively by plotting $\ln (K / \mathrm{T}) \mathrm{vs}^{-1}$ as listed in Table 5. Inspection of these data showed that the activation parameters $\left(\Delta H^{*}\right.$ and $\left.\Delta S^{*}\right)$ of the dissolution reaction of mild steel in $1.0 \mathrm{M} \mathrm{HCl}$ with the in- 
hibitors were less than those without inhibitors (blank). The positive signs of the change in enthalpies $\left(\Delta \mathrm{H}^{*}\right)$ reflect the endothermic nature of the steel metal dissolution process and means that the dissolution of steel is difficult. The values of enthalpies $\left(\Delta H^{*}\right)$ increase in the presence of the inhibitors more than those of the blank which means more heat required for the mild steel dissolution process to take place. This indicates that the corrosion rate is inhibited with the inhibitors under study and the surface becomes more protected. Further inspection of enthalpies $\left(\Delta \mathrm{H}^{*}\right)$ values in the presence of inhibitors, they increase as the concentration of the inhibitors increase, so the corrosion inhibition efficiencies are also increased by the same order.

The increase of $\Delta \mathrm{S}^{*}$ values means that the activated complex in the rate-determining step represents dissociation rather than association, indicating that an increase in disorder takes place.

\section{CONCLUSIONS}

The following conclusions can be derived from the results obtained in this study:

1- Plants extracts (TEX, CE, SM, and LM) acted as mixed type inhibitors.

2- The inhibition efficiencies of these compounds increase by increasing their concentrations and decreasing environment temperature.

3- The results obtained from the weight loss measurements were in a good agreement with those obtained from the potentiodynamic polarization and electrochemical impedance spectroscopy (EIS) methods.

4- The adsorption of these compounds on mild steel surface is a physical adsorption process and obeys Langmuir adsorption isotherm.

\section{REFERENCES}

[1] R. P. Bothi, R. A. Abdul, O. Hasnah and A. Khalijah, Acta Phys.Chim. Sin. 26 (2010) 2171.

[2] European Federation Corrosion (EFC), Working Part 7: Corrosion Education (2015), http://www.efcweb.org.

[3] M. Hosseini, M. Ehteshamzadeh and T. Shahrabi, Electrochim. Acta, 52 (2007) 3680.

[4] H. Tavakoli, T. Shahrabi and M. Hosseini, Mater. Chem. Phys.109 (2008) 281.

[5] R. A. Prabhu, T. V. Venkatesha, A. V. Shanbhag, G.M. Kulkarni and R.G. Kalkhambkar, Corros. Sci. 50 (2008) 3356.
[6] P. Kern, D. Landolt and Y. Abboud: J. Electrochem. Soc. 237 (2001)228.

[7] A. M. Al-Sabagh, N. G. Kandile, N. Amer, O. Ramadan and E. A. Khamis, J. Dispersion Sci. Technol. 33 ( 2012) 1307.

[8] A. M. Al-Sabagh, H. M. Abd-El-Baryb, R. A. ElGhazawya, M. R. Mishrifa and B. M. Hussein, Egyptian Journal of Petroleum, 20 (2011) 33.

[9] A. J. Aldykewicz, H. S. Isaacs and A.J. Davenport, J. Electrochem.Soc. 142 (1995) 3342.

[10] A. M. Al-Sabagh, M. Elsabee, O. E. Elazabawy and A. E. El-Tabey, J. Dispersion Sci. Technol . 31 (2010) 1288.

[11] B. Mu“ ller, React. Funct. Polym. 39 (1999) 165.

[12] M. K. Awad, M. S. Metwally, S. A. Soliman, A. A. El-Zomrawy and M. A. M. A. Bedair, J. Ind. Eng. Chem. 20 (2013) 796.

[13] S. A. Soliman, M. S. Metwally, S. R. Selim, M. A. Bedair and M. A. Abbas, J. Ind. Eng. Chem. 20 (2014) 4311.

[14] P. B. Raja and M. G. Sethuraman, Mater. Lett. 62 (2008) 113.

[15] P. B. Raja and M. Sethuraman, Mater. Corros. 60( 2009) 22.

[16] J. Buchweishaija and G. Mhinzi, Portugaliae Electrochim. Acta,26 (2008) 257.

[17] A. A. Rahim, E. Rocca, J. Steinmetz and M. Jain Kassim, Corros. Sci. 50 (2008) 1546.

[18] A. Rahim and J. Kassim, Recent Pat. Mater. Sci. 1 (2008) 223.

[19] A. M. Shah, A. A. Rahim, S. A. Hamid, S. Yahya and P. B. Raja,Pigm. Resin Technol. 40 (2010) 118.

[20] P. B. Raja and M. Sethuraman, J. Mater. Eng. Perform., 19 (2010) 761.

[21] P. B. Raja and M.G. Sethuraman, Mater. Lett. 62 (2008) 2977.

[22] A.Y. El-Etre, M. Abdallah and Z.E. El-Tantawy, Corros. Sci. 47 (2005) 385.

[23] A.Y. El-Etre, Corros. Sci. 45 (2003) 2485.

[24] E. A. Noor, J. Appl. Electrochem. 39 (2009) 1465.

[25] A. Minhaj, P. A,Saini, M. A.Quraishi and I. H. Farooqi, Corrosion Prevention and Control, 46 (1999) 32.

[26] M. A.Quraishi, A.Singh, V. K.Singh, D. K.Yadav and A.K.Singh,Mater. Chem. Phys. 122 (2010) 114.

[27] P. C. Okafor, E. E. Ebenso and U. J. Ekpe, Int. J. Electrochem. Sci. 5(2010) 978.

[28] I. B. Obot and N. O.Obi-Egbedi, Int. J. Electrochem. Sci. 4 (2009) 1277.

[29] M. Sangeethal, S. Rajendrani, T. S. Muthumegala and A. Krishnaveni, ZAŠTITA MATERIJALA, 
$52(2011)$

[30] J. C. da Rocha, J. A. da Cunha, P. Gomes and E. D’Elia, Corros. Sci. 52 (2010) 234.

[31] L. G. da Trindade and R. S. Goncalves, Corros.Sci. $51(2009) 1578$

[32] A. Y. El-Etre, J. Colloid Interface Sci. 14 (2007) 578

[33] P. C. Okafor and E. E. Ebenso, Pigm. Resin Technol. 36 (2007) 134.

[34] G. Gunasekaran and L.R. Chauhan, Electrochim. Acta, 49 (2004) 4387.

[35] L. R.Chauhan and G. Gunasekaran, Corros. Sci. 49 (2007) 1143.

[36] B. Anand and V. Balasubramanian, E-Journal of Chemistry, 8 (2011) 226.

[37] M. H. Hussin and M. J. Kassim, J. Phys. Sci. 21 (2010) 1.

[38] Tea water extract, ISO 9768 (1994).

[39] D. L. Pavia, G. M. Lampman, G. S. Kriz and R. G. Engel. A Small Scale Approach to Organic Laboratory Techniques:

A Small-Scale Approach, (2005).

[40] S. Haruyama, T. Tsuru and B. Gijutsu, J. Jpn. Soc. Corros. Engg. 27 (1978) 573.

[41] A. Lasia, Electrochemical Impedance Spectroscopy and Its Applications, Modern Aspects of Electrochemistry,

B. E. Conway, J. Bockris and R.E. White, Edts., Kluwer Academic/Plenum Publishers, New York 32 (1999) 143.

[42] L. Elkadi, B. Mernari, M. Traisnel, F. Bentiss and M. Lagrenee, Corros. Sci. 42 (2000) 703.

[43] I. L. Rosenfeld, Corrosion Inhibitors, McGrawHill, New York, 1981.

[44] A. M. Atta, O. E. El-Azabawy, H. S. Ismail and M. A. Hegazy, Corros. Sci., 53 (2011) 1680.
[45] C. Wagner and W. Z.Traud, Electrochem. 44 (1983) 391.

[46] R. N. Singh, N. Verme and W.R. Singh, Corrosion, 45 (1989) 222.

[47] L. M. Vracar and D. M. Drazic, Corros. Sci. 44 (2002) 1669.

[48] J. Bockris and D. Swinkls, J. Electrochem. Soc. 111 (1964) 763.

[49] I. Langmuir, J. Am. Chem. Soc. 38 (1916) 2221.

[50] M.Horsfall, Acta Chim. Slov. 52 (2005) 174.

[51] D.Karadag,Y.Koc,M.Turan and M.Ozturk, J. Hazard. Mater. 144 (2007) 432.

[52] H. M. F. Freundlich, J. Phys. Chem. 57 (1906) 385.

[53] A. K. Singh and M. A. Quraishi, J. Appl. Electrochem, 41 (2011) 7.

[54] A. K. Singh and M. A. Quraishi, J. Appl. Electrochem, 40 (2010) 1293.

[55] D. Bracher and A. D. Mercer, Br. Corros. J. 3 (1986) 12.

[56] A. M. Badiea and K. N. Mohana, Corros. Sci. 51 (2009) 2231

[57] S. Martinez and I. Stern, Appl. Surf. Sci. 199 (2002) 83 .

[58] X. H. Li and G. N. Mu, Appl. Surf. Sci. 252 (2005) 1254.

[59] A. A. El-Awady, B. Abd El-Nabey and S. G. Aziz, Electrochem. Soc. 139 (1992) 2149.

[60] M. S. Morad and A.M. Kamal El-Dean, Corros. Sci. 48 (2006) 3409.

[61] R. T. Vashi and V.A. Champaneri, Ind. J. Chem. Technol. 4 (1997) 180.

[62] S.S.A. El Rehim and H.H. Hassan, M.A.Amin, Mater. Chem. Phys. 70 (2001) 64.

[63] E. E. Ebenso, Mater. Chem. Phys. 79 (2003) 58. 